\section{EL CÓLERA: OPORTUNIDADES DE CONTROL Y RESISTENCIAS POPULARES. TUCUMÁN, 1886-1887 MARÍA CECILIA GARGIULO}

María Cecilia Gargiulo es becaria del CONICET con sede en el Instituto Superior de Estudios Sociales, CONICET / Universidad Nacional de Tucumán.

\section{Resumen}

El objeto de este trabajo es analizar los mecanismos de control social y las estrategias de resistencia de los sectores populares, activados durante la epidemia de cólera que se desató con virulencia en la provincia de Tucumán en el verano de 1886-1887.

La epidemia fue entendida por las clases dirigentes como una oportunidad única para profundizar el proyecto "civilizador». Los sectores populares reaccionaron a través de distintas estrategias. La firme desconfianza hacia los médicos, la persistencia de costumbres fuertemente combatidas, el levantamiento armado de más de 300 hombres para asesinar a los miembros de una de las comisiones de higiene, son algunas de las formas analizadas a lo largo de este trabajo.

\section{Summary}

The purpose of this paper is to analyze the mechanisms of social control and the strategies of resistance of popular sectors that were set in motion during the epidemic of cholera which broke out violently in the province of Tucumán in the summer 1886-1887.

The epidemic was considered by the ruling classes as a unique opportunity to progress with the «civilizing» project. The popular sectors reacted to the attempts to invade their lives, bodies and customs through different strategies. The firm distrust of doctors, the persistence of customs strongly attacked, the armed uprising of more than 300 men to murder the members of one of the hygiene commissions are some of the ways analyzed throughout this paper. 